\title{
SOILS OF NORTH AUCKLAND
}

By N. H. TAYLOR, Wellington, and C. F. SUTHERLAND, Whangarei, both of Soil Bureau, Department of Scientific and Industrial Research.

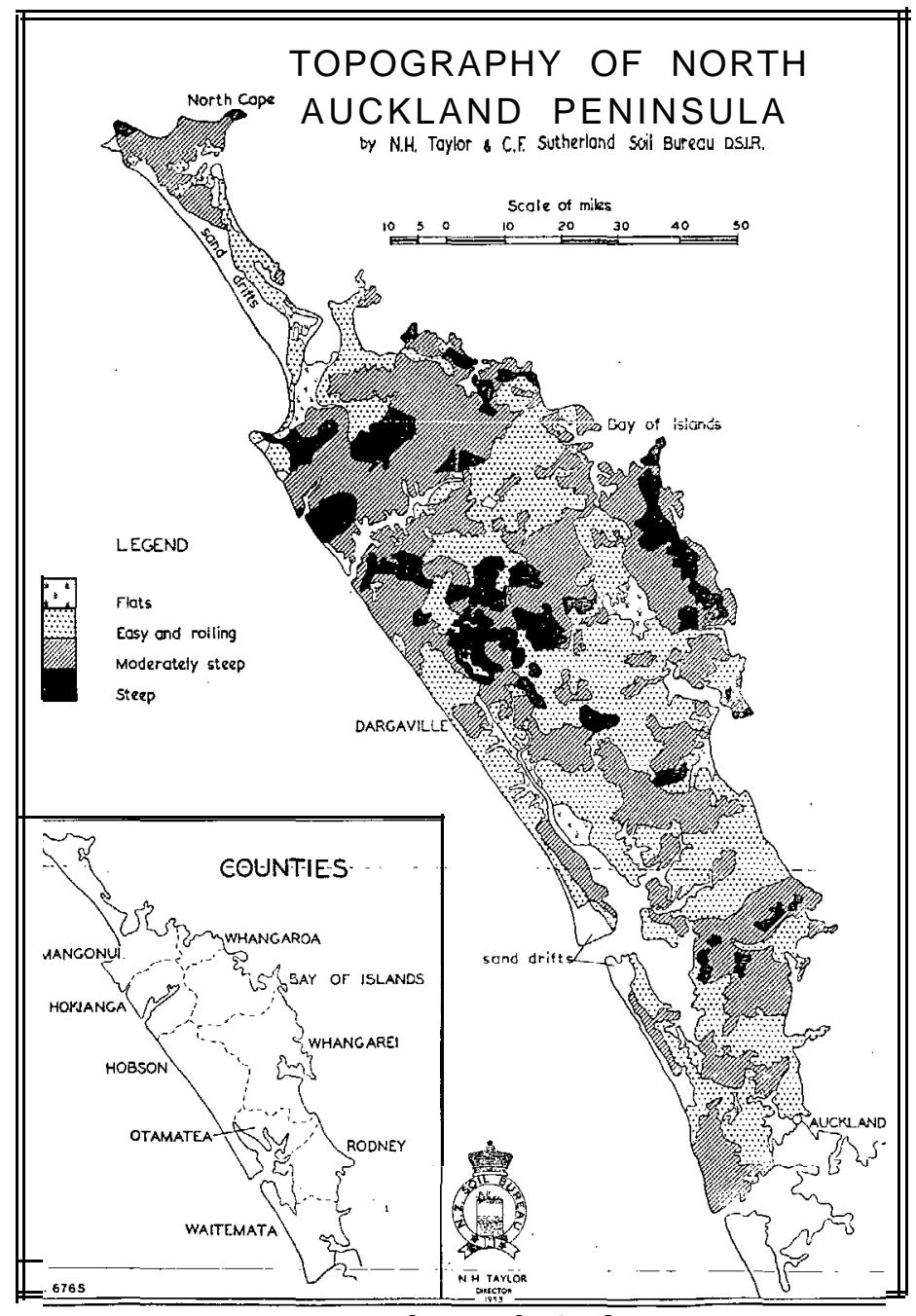

Topography and Geology

The topography of North Auckland is varied and somewhat intricate, as $\underset{25}{\text { geological structures parallel }}$ 
with the north-west trend of the peninsula are broken across by structures trending north-east parallel with the main axis of New Zealand. In the southern part of the peninsula low rolling downland carved from mudstones and sandstones is interrupted by moderately steep sandstone hills rising to 600 or $700 \mathrm{ft}$. above sea level. In the northern half of the peninsula the rolling areas are smaller; moderately steep and steep hills predominate, mainly of sandstone, greywacke, and volcanic rocks. West of the Bay of Islands is an extensive basaltic plateau tilted east, and similar smaller volcanic plateaus occur near Whangarei. North from Dargaville the basalt-covered plateau of Tutamoe is $2000 \mathrm{ft}$. above sea level, and slopes gently toward the north-west. North-east from Kaitaia and south-west from Dargaville the coastline has been straightened by large accumulations of sand. Flats close to sea level border the Kaipara Harbour, and similar flats occur north of Kaitaia and a few miles south and north of Whangarei. Peat-filled hollows occur in association with these flats and with the sand formations bordering the west coast.

\section{Climate}

The climate of North Auckland is moist and warm. Over the southern half of the peninsula and again in the far north the rainfall is approximately $50 \mathrm{in}$. per annum. Over most of the northern half the rainfall is 60 to $70 \mathrm{in}$. per annum and it rises sharply to over $100 \mathrm{in}$. per annum on the Tutamoe Plateau south-east of Hokianga Harbour. Most of the peninsula receives between 114 and 200 rain days per annum. The contrast between light summer and heavy winter rainfall is greater in North Auckland than in any other part of New Zealand. The average fall in December is about half that in May. November, December, and January each have low falls.

The mean annual temperature at sea level is about 58 degrees $\mathrm{F}$., the temperature being 3 or 4 degrees $\mathrm{F}$. higher on the east coast than on the west. The mean relative humidity is rather high (about 80 per cent.). South-westerly winds predominate at all times of the year, but north-easterlies also are frequent, especially in summer and autumn.

Cyclones which affect the district usually approach from some northerly direction. North-easterly or easterly gales prevail as they approach and on rare 


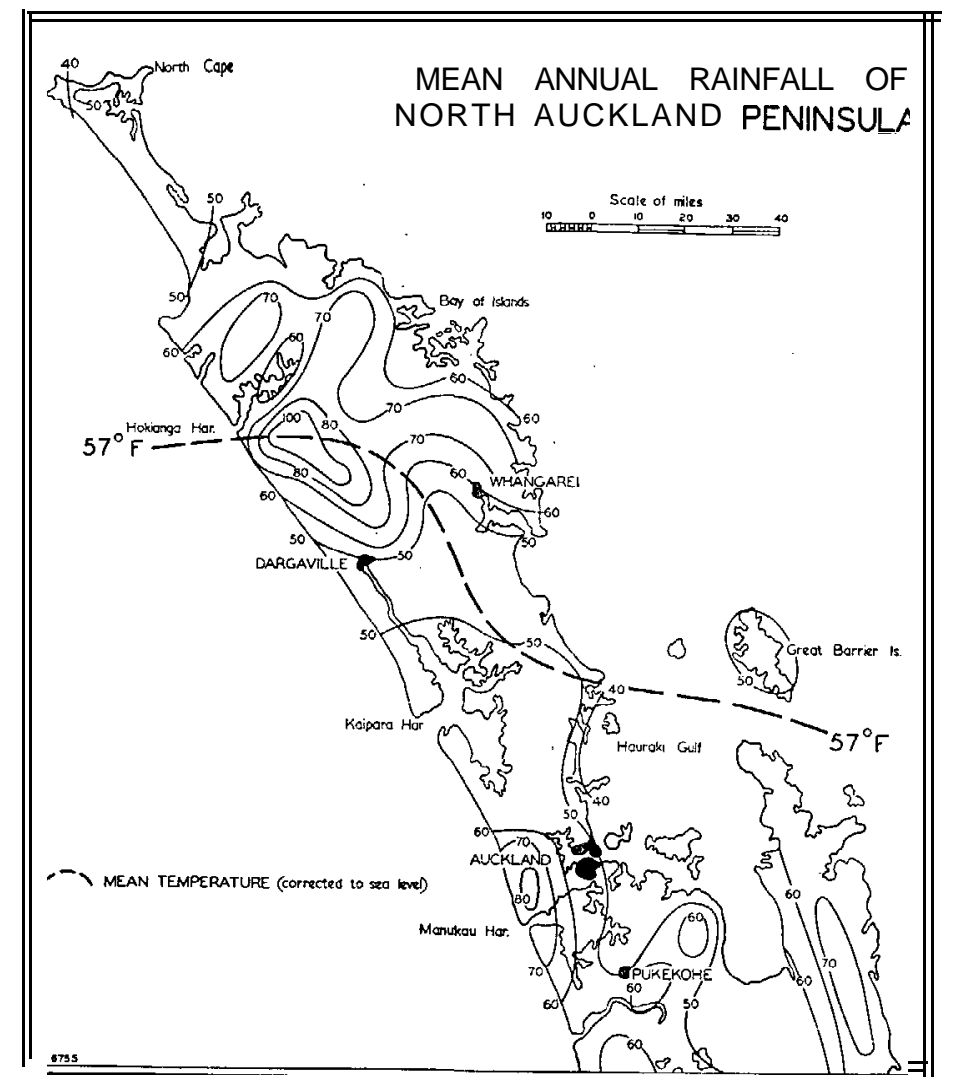

occasions they are followed by gales from a westerly quarter--The - gales-are-liable-to-be-severe-and-muchdamage is caused by them. The frequency of the storms is 6.7 per annum and of severe storms $1.3 \mathrm{per}$ annum. Very heavy rains usually accompany the cyclones and flooding is rather frequent.

\section{Native Vegetation}

In primitive times 'North Auckland was covered for the most part with mixed sub-tropical rain forest. Manuka scrub occupied considerable areas of the rolling lowlands and sand-grass and manuka covered the coastal dunes.

In some districts-for example, north of Kaihukauri was locally the dominant tree, but in general the forest was a mosaic, kauri and the podocarps being more in evidence on ridge tops and steeper slopes, and 


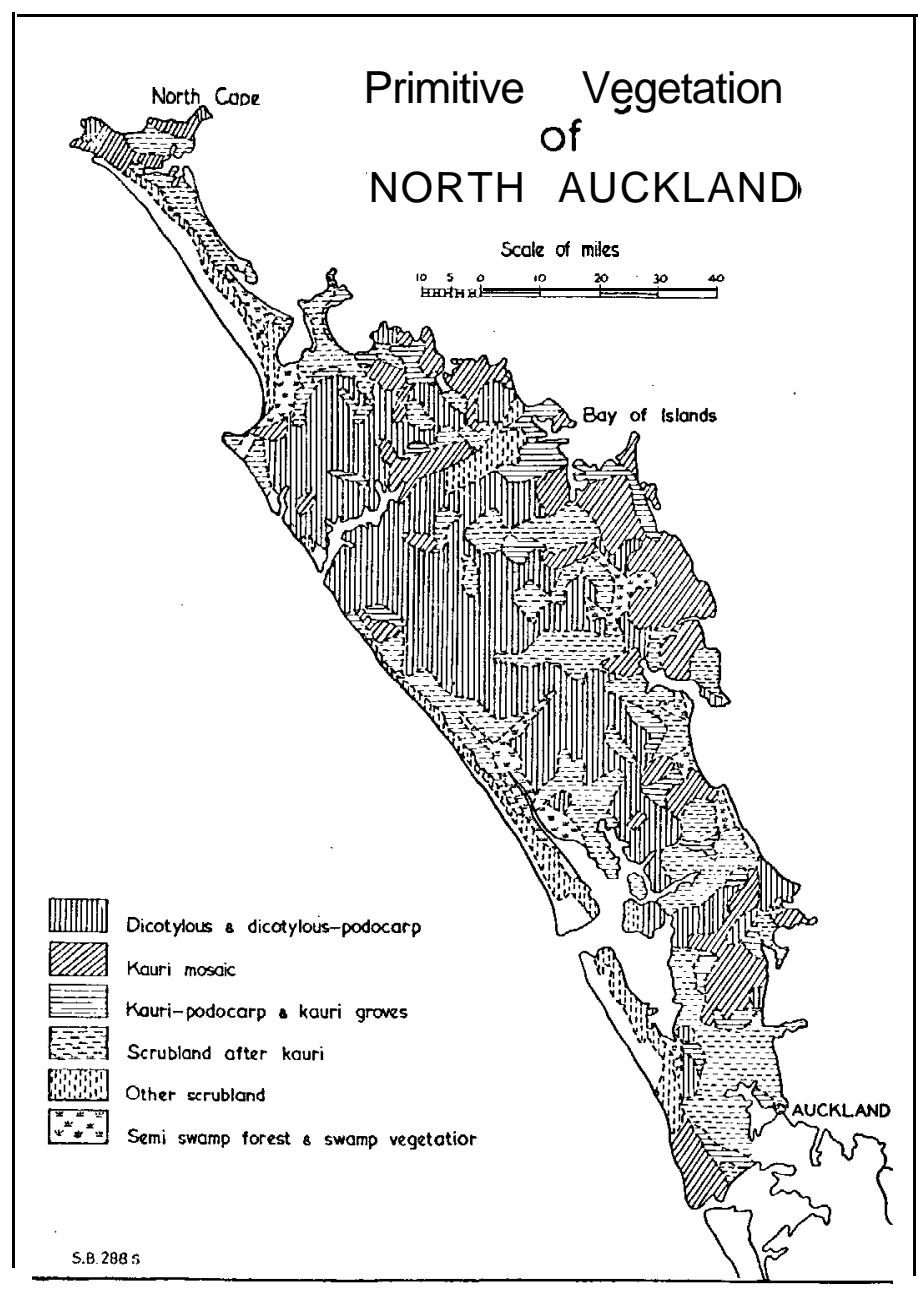

the broad-leaved trees (with taraire dominant) occupying the lower slopes and gullies. Certain fertile areas supported forest composed almost entirely of broadleaved trees such as puriri, kohekohe, and taraire. The wetter flats were covered largely with kahikatea semiswamp forest.

Apart from the coastal areas, where the vegetation is kept in check by the salt-laden wind, the scrub, lands are of two main types: The "ironstone" lands of the basalt plateau west of Kerikeri which were formerly covered with mixed forests and the' gum28 
lands which formerly carried kauri. The date when the forest retreated from these lands is not known. On some areas the change has been comparatively recent, for pits left by the overturning of trees and even logs of the pre-existing forest are yet found, but in other areas the kauri gum and roots of trees cemented in the soil horizons are the only remaining traces. The appearance of the soil profile and the accumulation of moa "cropstones" on some of the gumland areas favours the conclusion that they have been scrublands for a long period, but other scrub-covered areas almost certainly owe their origin to early Maori occupation.

From the soil scientist's point of view the forest trees fall into two divisions-the broad-leaved dicotylous trees such as puriri, kohekohe, taraire, and tawa, which give rise to mull on the forest floor, and the podocarp and conifer trees such as totara, rimu, tanekaha, and kauri, which give rise to mor. Under the mull-producing trees the typical forest floor consists of a shallow litter of dead leaves which lie directly on the mineral soil. The top of the mineral soil is mellow and fertile and is stained brown with the humus formed from the rapidly decomposing litter. Under the mor-producing trees the profile is very different. A litter of leaves, twigs, and bark decomposes slowly and a markedly acid humus tends to accumulate on the surface, the drainage from which impoverishes the mineral soil below.

Every Northland farmer knows how in the early days of settlement the, quality of the land was judged by the type of vegetation growing on it. Puriri land, for example, was judged to be the best and kauri land the $\overline{\mathrm{w}} \mathrm{w} \overline{\mathrm{r}} \overline{\mathrm{s}} \mathrm{s}$.

\section{S,oils}

The soils of North Auckland reflect the influence of rock, climate, and vegetation more clearly thàn those of any other part of New Zealand.

Under the warm, moist climate the rocks weather rapidly to form clays which differ according to the kind of rock. These: clays in turn tend to become leached under the heavy rainfall, a process which has been intensified or retarded according to the particular type of native vegetation. Thus the majority of the Soils are warm, heavy-clayswith-thin- topsoils-and-lowsubsoil fertility-a combination of properties which marks them off from other soils of New Zealand. They are, in fact, a link between the temperate and tropical soils of the South Pacific region and broadly the 


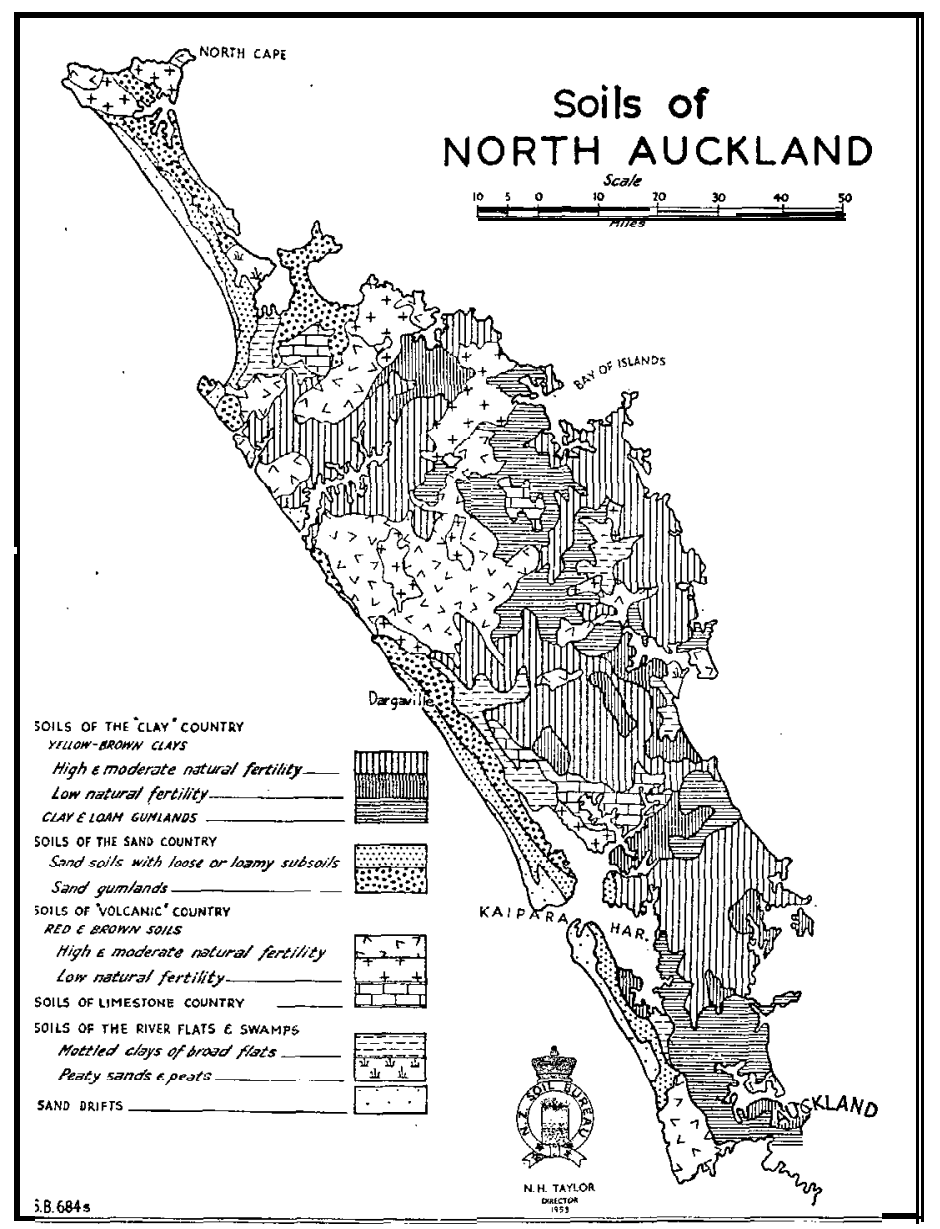

farming problems may be said to lie in adjusting to these conditions methods of farming evolved for the cooler, lighter-textured, better aerated, and quicker draining soils of the temperate regions.

Although the soils are unusually diverse, they may for the purposes of this discussion be classified broadly as follows :-

1. SOILS OF THE "CLAY" COUNTRY-from sandstone, mudstone, greywacke, etc.

(a) Yellow-brown clays

of high and moderate natural fertility . Mixed forest

(b) Yellow-brown clays

of low natural fertility . . . . . Kauri-podocarp forest

(c) Clay and loam gumlands . . . . . . . . Scrub after kauri 
2. SOILS OF THE SAND COUNTRY-from coastal sands.

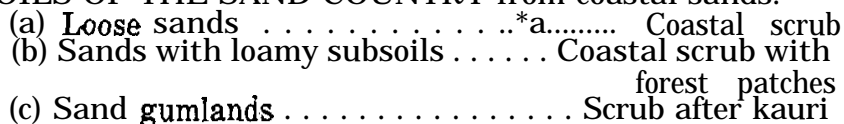

3. SOILS OF THE "VOLCANIC" COUNTRY-from basic and intermediate igneous rocks.

(a) Red and brown soils

of high and moderate natural fertility . Mixed forest

(b) Red and hrown soils

of low natural fertility ...... Scrub after forest

4. SOILS OF THE LIMESTONE COUNTRY-from Limestone and associated rocks ............. Mixed forest

5. SOILS OF THE RIVER FLAT AND SWAMPY COUNTRY

from alluvium, peat, etc.

(a) Loamy soils of the river flats . . . . K . Mixed forest

(c)

(c) Peaty sands and peats ......... Scrub, rushes, etc.

(The approximate areas of these soils, totalling some 5200 sq. miles, are given in Table 1.)

\section{SOILS OF THE "CLAY" COUNTRY}

The "clay" country of North Auckland is a somewhat indefinite local expression used to embrace soils mainly of moderate to low fertility which cover the undulating and hilly country carved for the most part from mudstone, sandstone, and greywacke rocks. It includes the gumland soils with heavy subsoils and with topsoils of various textures, as well as the soils of the closely associated swampy gumland flats. The more fertile soils from limestone and the fertile mottled soils of the broad flats are generally excluded.

The soils, are of two main kinds: the yellow-brown clays, under forest cover, which may be further subdivided_according to fertjlity, and the scrub-covered gumlands with topsoils of loam or clay texture.

(a) The Yellow-brown clays of high and moderate natural fertility occupy large areas (1410 sq. miles) of rolling and hill country between Waiwera and Dargaville, between Whangarei and Bay of Islands, and surrounding Hokianga Harbour. The soils with high natural fertility occupy a restricted area, a well-known type being the Puhoi clay loam. They are formed typically under taraire-puriri forest on calcareous mudstone and sandstone. They have brownish mellow granular_clay loam topsoils and yellowish-brown nutty subsoils. Many of the soils are somewhat shallow, the ${ }^{-}$ rock being within $2 \mathrm{ft}$. or so of the surface. They are leached of calcium carbonate, but are well supplied with bases. The soils of moderate natural fertility are more extensive, well-known types near Whangarei be- 
ing the Waiotira clay loam, formed on sandstone and the Marua clay loam on greywacke. They are developed under mixed taraire-podocarp-kauri forest in which the mull-forming taraire predominated. They have grey-brown granular clay loam or clay topsoils with yellowish-brown blocky clay subsoils. These soils are moderately acid and are moderately well supplied with bases. The rolling land when sown to grass and adequately topdressed with lime and phosphate is used for dairying and fattening. The hills are used for grazing.

(b) The yellow-brown clays of low natural fertility occupy some 400 sq. miles scattered throughout North Auckland and commonly cover a transition belt between the more fertile yellow-brown clays and the gumland soils. A good example of these soils is the Rangiora, clay formed on greywacke. They developed under forest containing many mor-forming trees such as kauri and rimu, but, because of their low fertility, scrub in many areas replaced this forest where it had been destroyed by fire. They have typically greyish topsoils with weakly developed granular or nutty structures and yellow-brown or greyish-brown harsh nutty or blocky subsoils. The more developed soils show marked signs of degradation indicating that they are a transition to gumlands: the surfaces of the subsoil aggregates are stained with organic matter and in places are covered with a grey, structureless coating. The soils are moderately to strongly acid and are well leached of bases.

These soils support fair pastures when adequately topdressed with lime and superphosphate and on the easier country many dairy and fat lamb farms are situated on them. Because of the greater difficulty in topdressing, pastures on the hill country are less easy to maintain.

(c) The clay and loam gumlands occupy approximately $1000 \mathrm{sq}$. miles. They occur in many places in North Auckland, and are especially extensive on the easy rolling and hilly land north of Whan,garei, south of Dargaville, and north of Auckland, They have developed under kauri forest, but were covered with low scrub and rushes when the first settlers arrived. The presence of kauri gum and roots in the soils indicates that they formerly supported kauri forest. They have thin grey topsoils overlying light-grey siliceous horizons which in places are cemented, Where the topsoil is a sandy loam the light-grey horizon is under- 
lain in places by humus and iron pans. The gumlands are of three main kinds: the Waikare gumlands, which are grey and grey-brown clays; the Wharekohe, which have a well-developed, light-grey, silty surface horizon cemented in places to form a pan ; and the Kara, which are wet soils on low-lying flats. All the gumland soils are strongly acid and well leached of bases.

Despite their unattractive appearance in the natural state, these soils can be brought to support good dairy pastures. On these highly siliceous soils soluble phosphates give a quick response when the acidity is corrected with lime. Wharekohe and Kara soils require potash also. Drainage is required on lowlying areas, particularly on the Kara soils. There is also a difficult drainage problem on lower slopes at the junction of the Waikare and Wharekohe soils where wafer draining from the adjacent clay slopes becomes perched on the cemented: pan of the Wharekohe soils.

\section{SOILS OF THE SAND COUNTRY}

The sand country embraces the soils on fixed coastal sands, mainly of wind-blown origin, bordering much of the west coast and parts of the east coast of North Auckland. The soils are of three main kinds: the loose sands under coastal scrub, the sands with loamy subsoils under coastal scrub with patches of forest, and the sand gumlands under scrub which has replaced kauri forest.

(a) The loose sands occupy about 60 sq. miles of hilly and rolling land, flanking the moving dunes and sand beaches on the west coast near Ninety Mile

-- Beach,-.Kaipara Harbour, and Muriwai, and in small areas in a number of places on the east-coast. The-main soil type is the Pinaki sand. It has developed on young dunes which have been fixed by vegetation. As the subsoil is loose, the soil is droughty, except where groundwater approaches the surface.' The soil is low in phosphate, but has a moderate supply of bases. It is used for grazing. '

(b) The sands with loamy subsoils cover some 160 sq. miles, mostly on rolling land between Hokianga and Muriwai, north of Kaitaia, and near Manawai. The Red Hill sand west of Dargaville and the Houhora sand of the far north-are-the-moreeextensiae-types. The soils have formed on the older sandhills fixed by weathering. Due to their heavier subsoils they retain moisture better than do the soils on loose sands. They are very low in phosphate and have a moderate supply 
of bases. These light-textured soils differ from most North Auckland soils in having a low lime requirement. Pastures on them respond to phosphate and potash. They are used for fattening and dairying.

(c) The sand gumlands occupy approximately 260 sq. miles of rolling and hilly land and are extensive north of Mangonui and Kaitaia and between Hokianga and Muriwai. They have low natural fertility, a good example being the ' $\mathrm{Te}$ Kopuru sand west of Dargaville. The soils are closely related to the clay and loam gumlands, having developed under kauri forest which was later replaced by scrub. They have brownish-grey or grey topsoils overlying a white, very leached layer which in places is cemented; beneath this are pans of humus and iron. These soils are extremely acid and are low in phosphate and bases. Available soil copper is also low. In general, these soils are inferior to the other gumlands and pastures on them are of poorer quality.

\section{SOILS OF THE "VOLCANIC" COUNTRY}

The term volcanic is applied locally to red and brown soils derived from basic and intermediate volcanic rocks, for example? basalts and andesites. These rocks, on weathering, give rise to clays high in iron and aluminium. Soils with such clays have welldeveloped structures and are friable, but they also have a marked power to fix soluble phosphates in a form relatively unavailable to plants. The soils formed on basalts are distinguished. from those formed on andesites by their greater friability and lack of stickiness.

(a) The red and brown soils of high and moderate natural fertility occupy some 1050 sq. miles and are formed under mixed forest in which mull-forming trees predominated. The andesitic soils are located south of Herekino and Hokianga Harbours, near Bream Head, and north of Manukau Harbour. They have brown to greyish-brown topsoils with welldeveloped granular structure. The subsoils are brown and granular. The basaltic soils are dark brown and are very friable. They occur near Kaikohe and Whangarei. These fertile soils are but slightly acid and have a moderate to high supply of exchangeable bases. They carry good pastures which to be maintained need dressings of superphosphate and lime, particularly where the natural fertility is moderate. In addition, 
the soils from basalt respond to potash. The easy lying soils, where they are deep or have been deepened by the removal of boulders, are used for dairying and fattening and in places for market gardens and orchards. The shallow bouldery soils which dry out readily are used for grazing. Much of the rolling land is used for fattening and grazing in conjunction with the neighbouring hilly land.

(b) The red and brown soils of low natural fertility cover approximately 300 sq. miles and belong to two main classes: the strongly acid granular soils developed near Aranga in Awarua Valley and west of Whangaroa Harbour and the moderately acid ironstone soils lying west of Bay of Islands. The Rangiuru soils are typical of the strongly acid soils. They have thin brown to grey-brown topsoils with well-developed granular structure. The subsoils are compact with coarse, harsh structures. The supply of bases is low. Much of this land is in scrub and its fertility has been further depleted by sheet erosion following scrub fires, the fine granular topsoil washing readily from above the compact subsoil. Where soil moisture is satisfactory these soils carry fair pastures if heavily limed and topdressed with phosphate and potash;

The ironstone soils (100 sq. miles) cover the flat and gently undulating surface of the older basalt sheets of the Bay of Islands district. They were formed under mixed forest which was later replaced by scrub. They are old soils being moderately acid and well leached of bases throughout the profile. They

--- are_characterised by a layer of ironstone (limonite) concretions, which gives rise to the local name of "Ironstone" soils. In most places the layer of concretions is from 3 to. 12in. thick and lies 6in. or so below the surface. In some localised areas where it is very thick it extends to the surface. Okaihau friable clay is typical of the ironstone soils which have several good features: they are friable and easy to work at all times of the year and they occur on a gently undulating surface in an area well watered by streams. Against this, however, must be placed the very low plant food status, the power of the soils to fix soluble phosphates in - a -form-comparatively - unavailable to plants, and the fact that pastures on them tend to dry out rapidly in summer. Adequately topdressed with lime, phosphate, and potash, they can be made to grow fair pastures which are used for grazing. The greater part of the soils is, however, still a scrub. 


\section{SOILS, OF THE LIMESTONE COUNTRY}

The soils of the limestone country occupy some 90 sq. miles and are derived from calcareous parent materials. They consist typically of a dark soil overlying soft, white limestone. They occur near Kaitaia, southeast of Kaikohe, and near Maungaturoto. Their special characteristics are best illustrated by the Arapohue soil, a dark grey, heavy, granular soil leached of calcium carbonate in the topsoil, neutral in reaction, saturated with bases, and well supplied with humus derived from the litter of the forest trees and shrubs which it supported. In the Motatau, Konoti, and Dairy Flat soils similar profiles are found close to limestone outcrops and in other places where the soil is shallow over limestone. Where, however, the soil is deeper than 2ft., all stages of soil development are encountered, the soils ranging from yellow-brown clays, well supplied with bases, to leached, mature podzols, depending on the stability of the terrain and the kind of vegetative cover. Because of the relatively high rainfall of 50in. to 60in. per annum and the poor internal drainage of these heavy-textured soils, the subsoils are mottled grey and brown. The limestone soils are fertile and are used mainly for fattening.

\section{SOILS OF THE RIVER FLAT AND SWAMPY COUNTRY}

The soils of the river flat and swampy country are of three main kinds: the loamy soils of the river flats, the mottled clays of the broad flats, and the peaty sands and peats.

(a) The loamy soils of the river flats, covering approximately 140 sq. miles, are formed on alluvium and, as sediments are periodically added to their surface, they tend to be deep and to lack differentiation into the normal horizons of older soils. They differ according to the type of alluvium brought down by the rivers and for the most part are deep, brown mellow loams, with scarcely any melanised topsoil where accumulation is rapid, or with a deep, dark, granular topsoil where accumulation is slow. They occur on narrow flats bordering the upper or middle reaches of most of the main rivers and streams. Where drainage is adequate the soils are highly fertile and, because of the mellow consistence and relatively even conditions of fertility throughout the profile, plants grow well and develop vigorous rooting systems. They are used mainly for dairying and fattening. 
(b) The mottled clays of the broad flats are some 210 sq. miles in area and owe their distinctive characteristics to the presence of ground water at or near the surface for prolonged periods during the year. This causes the formation of a grey layer, commonly mottled with rust colours, and known as the "gley" horizon. They occur near Kaitaia, bordering the Wairoa River near Dargaville and Ruawai, near Waipu, and near Helensville. They are situated on low-lying flats where the water-table tends to be permanently high. Their topsoils are grey-brown to grey and in some small areas are peaty. The subsoils are grey and are mottled rusty-brown in some types. Most of the soils are moderately acid and have only a moderate supply of bases. These mottled clays need draining before they can be satisfactorily farmed, but where they are drained and topdressed with lime and phosphate they can be; made to support good pastures which are used for fattening and dairying. Being moist, the soils warm up more slowly in the spring and cool more slowly in the autumn than do neighbouring well-drained soils. Hence pastures on them have a later and less pronounced spring flush of growth, remain greener during the summer, and continue growth later in the autumn. For these reasons they have special value when farmed in conjunction with the drier soils.

(c) The peaty sands and peats occupy approximately 120 sq. miles and are formed in hollows and on low flats where the water-table is permanently high and anaerobic conditions lead to accumulation of organic matter. They occur in many places in North Auckland, especially north of Kaitaia, near Hikurangi, One Tree Point, Waipu, and Mangawai, and in numerous small areas among the sand country between Dargaville and Muriwai The peaty sands are underlain by a humus charged hardpan at a depth of 18 to $24 \mathrm{in}$. from the surface. The sand grains are bleached and fragments of kauri gum occur throughout the profile. Most of the peats are deep, acid soils. Many of the peaty soils are low in available copper, or have a low content of copper in relation to their content of molybdenum, and animals pastured on such areas suffer from copper deficiency. This can be corrected by topdressing the soils with copper sulphate. Pastures on the peaty soils respond to lime, phosphate, and potash. 


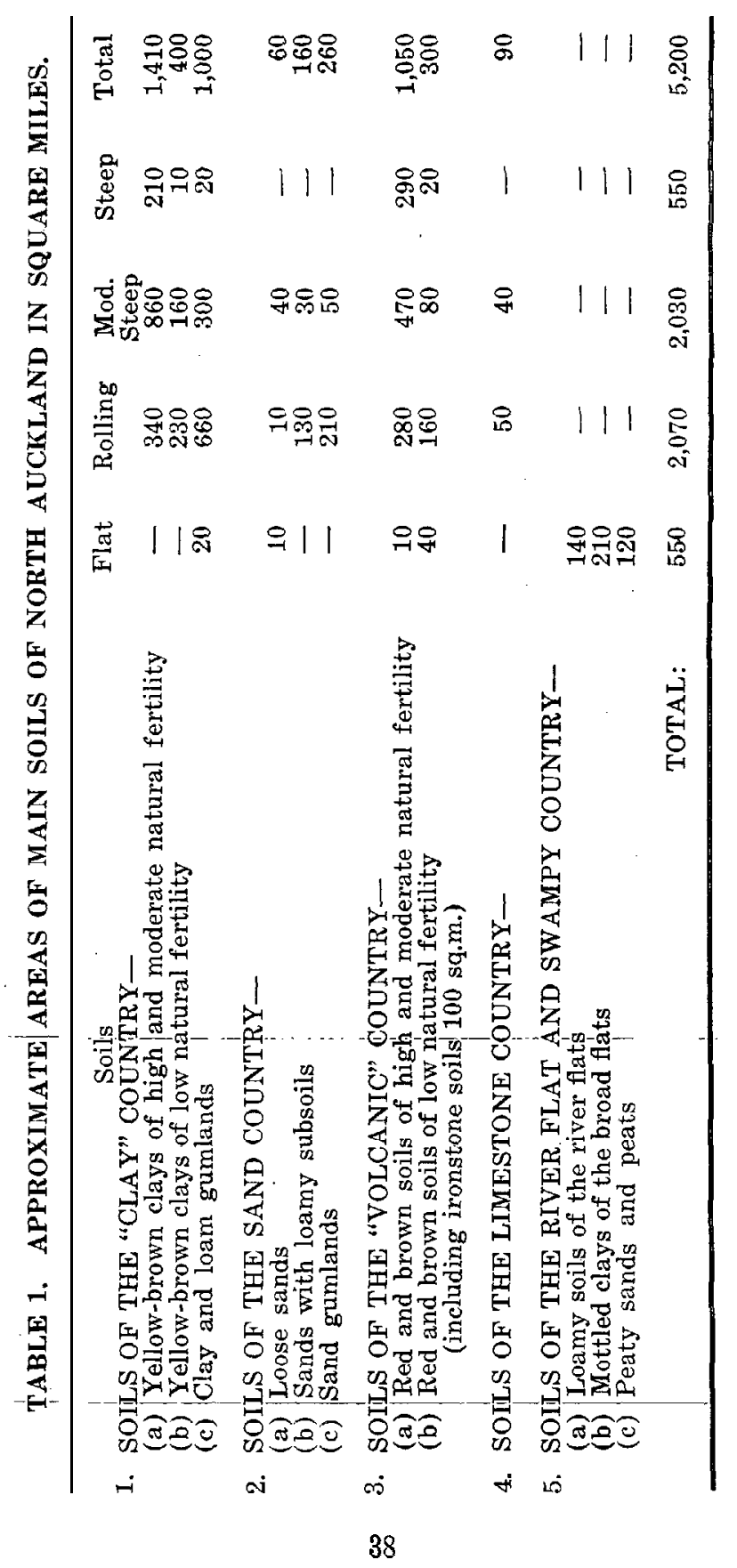

